\title{
Marta SORDYL*
}

\section{Kryzys w Argentynie lat 1999-2002 - przyczyny i niewykorzystane srodki zaradcze}

\section{Uwagi wstępne}

Argentyna jest państwem, którego gospodarcza historia wydaje się zaskakująca. Kraj niezwykle bogaty w zasoby naturalne i ludzkie, jeszcze w latach międzywojennych należał do najlepiej rozwiniętych państw świata. Okres przed drugą wojną światową charakteryzował się szybkim wzrostem gospodarczym. Wysoki stopień otwartości gospodarki przyczyniał się do dynamicznego rozwoju i korzystnej sytuacji ekonomicznej, określanej mianem „cudu argentyńskiego". Po wojnie nastąpiła jednak radykalna zmiana reżimu gospodarczego - zastąpienie wolnego handlu strategią industrializacji poprzez substytucję importu. Efekty realizacji tej strategii okazały się dla gospodarki zgubne: wzrost uległ zahamowaniu, pojawiły się narastające problemy z inflacją i deficytem budżetowym; kumulacja nieprawidłowości prowadziła do kolejnych epizodów hiperinflacji i trudności płatniczych państwa. Trwały one przez całą dekadę lat 80. z punktem szczytowym w latach 1989-1991'.

Radykalne reformy przeprowadzone w latach 90. w ramach tzw. Planu wymienialności przyniosły początkowo odwrócenie negatywnej tendencji. Powrót do liberalizmu, ograniczenie roli państwa w gospodarce poprzez prywatyzację i deregulację poszczególnych rynków, a także całkowite przeformułowanie zasad prowadzenia polityki monetarnej, umożliwiły stabilizację środowiska makroekonomicznego, poprawę efektywności i przywrócenie szybkiego tempa wzrostu. Argentyna stanowiła modelowy przykład realizacji reguł „konsensusu waszyngtońskiego" oraz dowód, że zastosowanie zasad liberalizmu, prywatyzacji i deregulacji stanowi pewną drogę do gospodarczego sukcesu.

Wbrew powszechnym oczekiwaniom korzystna sytuacja nie trwała długo. W nowym systemie ekonomicznym nie zdołano ustrzec się błędów, które - w połączeniu z działaniem czynników zewnętrznych - doprowadziły do kryzysu gospodarczego, zasługującego w pełni na miano ekonomicznej i społecznej katastrofy. Jest rzeczą zastanawiającą, że choć wprowadzeniu systemu izby walutowej

- Autorka jest absolwentką AE w Krakowie. Artykuł powstał na podstawie pracy magisterskiej pt. Rola systemu izby walutowej w kryzysie argentyniskim z lat 1999-2002, obronionej w $2003 \mathrm{r}$. Artykuł wpłynął do redakcji w lipcu 2003 r.

1 Kryzysy, które miały miejsce w najnowszej historii Argentyny, były przedmiotem wielu opracowań, m.in. [Iwanicz-Drozdowska (red.), 2002], [Małecki, et al., 2001], [Żuławska, 1994]. Wśród prac obcojęzycznych wymienić można przykładowo [Veganzonés, Winograd, 1997], [von Stein (Hrsg.), 2001]. 
w Argentynie towarzyszyły głosy ostrzegawcze, że nie spełnia ona kryteriów optymalnego obszaru walutowego ze Stanami Zjednoczonymi, to jednak krytyka szybko ucichła, kiedy Plan wymienialności zaczął przynosić efekty. Być może w pewien sposób przyzwyczajono się patrzeć na Argentynę jako „przypadek modelowy", przykład trochę niespodziewanego, ale niepodważalnego sukcesu.

Dlatego też głębokość kryzysu lat 1999-2002 oraz jego społeczne następstwa okazały się zaskoczeniem nawet dla tych spośród obserwatorów, którzy przewidywali jego wybuch już od czasu dewaluacji w Brazylii w styczniu 1999 r. Wcześniej nie przewidywał go niemal nikt; funkcjonujący od kwietnia 1991 r. Plan wymienialności, wraz ze stanowiącym jego podstawę systemem izby walutowej, zdawał się spełniać swoje zadania. W rzeczywistości gospodarka argentyńska wydawała się być stabilna co najmniej do wybuchu kryzysu rosyjskiego. Nawet później uwaga międzynarodowych rynków finansowych i instytucji skupiała się raczej na Brazylii, której brak równowagi makroekonomicznej był bardziej widoczny, a powtarzające się ataki spekulacyjne doprowadziły ostatecznie do rezygnacji z pasma wahań kursu i ostrej dewaluacji reala w początkach $1999 \mathrm{r}$.

Pod względem PKB per capita sytuacja w Argentynie aż do 1997 r. była lepsza niż w pozostałych krajach regionu, chociaż jego wzrost uległ pewnemu zahamowaniu, a bezrobocie utrzymywało się na wysokim poziomie. Wobec relatywnie korzystnych warunków zewnętrznych (poprawa terms of trade, napływ kapitału, wzrost gospodarki światowej) możliwe było utrzymanie szybkiego rozwoju mimo zachwiania spowodowanego kryzysem tequili w $1995 \mathrm{r}$.

Kilka miesięcy po spadku tempa wzrostu gospodarczego, które w 1999 r. dotknęło wszystkie kraje Ameryki Łacińskiej, gospodarki państw sąsiednich rozpoczęły powolny proces odbudowy. W Argentynie jednak recesja utrzymywała się i pogłębiała, prowadząc do unicestwienia pozytywnych efektów poprzednich kilku lat po wprowadzeniu Planu wymienialności. Zewnętrzne warunki w odniesieniu do Argentyny - spadek terms of trade, odwrócenie się kierunku przepływów kapitału w wyniku kryzysu rosyjskiego oraz zastój gospodarki amerykańskiej i światowej pod koniec wieku - nie były bardziej niekorzystne niż odpowiednio dla innych państw regionu. Oznacza to, że skala reakcji na te zjawiska wynikała z większej wrażliwości na działanie szoków zewnętrznych, nieadekwatności polityki makroekonomicznej lub kombinacji obu elementów.

Przedmiotem uwagi niniejszego artykułu nie jest szczegółowa analiza przebiegu kryzysu; jest nim raczej próba określenia przyczyn niedawnej katastrofy gospodarczej w Argentynie oraz udzielenie odpowiedzi na pytanie, dlaczego odpowiednio wcześnie nie dostrzeżono symptomów kryzysu lub - jeśli zdawano z nich sobie sprawę - nie podjęto skutecznych środków zapobiegawczych.

\section{Przyczyny kryzysu}

Ustalenie przyczyn kryzysu w Argentynie wywołuje wiele kontrowersji. Alternatywne wyjaśnienia koncentrują się na różnych czynnikach, które tłuma- 
czyć mają wystąpienie i przebieg załamania argentyńskiej gospodarki. Najogólniej wyodrębnić można trzy grupy przyczyn: przyjęty przez Argentynę reżim kursowy, błędy w polityce ekonomicznej, głównie fiskalnej, i związane z nimi zaburzenia polityczne, a także zbieg wielu znaczących szoków zewnętrznych. Trudno stwierdzić, które z tych zjawisk odegrało decydującą rolę; wydaje się jednak, że najistotniejsze było połączenie i wzajemne wzmacnianie negatywnych czynników należących do wszystkich wymienionych grup.

Niewłaściwy wybór systemu walutowego jest często wymieniany jako główna przyczyna kryzysu. Wprowadzony w kwietniu 1991 r. ustawą o wymienialności system izby walutowej, ustanawiający sztywne powiązanie wartości pieniądza krajowego z dolarem amerykańskim, umożliwił skuteczne zwalczenie inflacji oraz stabilizację środowiska makroekonomicznego. Mimo swych niewątpliwych zalet, niósł z sobą także wiele niebezpieczeństw dla gospodarki kraju, których znaczenie ujawniło się w długim okresie.

W retrospektywnym ujęciu nie ulega wątpliwości, że z punktu widzenia struktury produkcji i handlu zagranicznego Argentyny usztywnienie kursu peso w stosunku do dolara było posunięciem niekorzystnym. Argentyna doświadcza innych szoków niż Stany Zjednoczone i nie tworzy wraz z nimi optymalnego obszaru walutowego. Poza tym znaczny udział w jej wymianie handlowej przypada na kraje, których waluty ulegają znacznym fluktuacjom względem dolara. W czasie wprowadzania Planu wymienialności gospodarka Argentyny była jednak stosunkowo zamknięta, toteż uważano, że ewentualne niekorzystne zmiany terms of trade nie powinny wywołać znacznych negatywnych skutków ${ }^{2}$. Ponadto wprowadzenie Planu miało na celu przede wszystkim stabilizację monetarną; w tym kontekście wymiana handlowa nie była najbardziej istotna [Antinolfi, Keister, 2001].

Rezygnacja z autonomii monetarnej oznaczała jednak niemożność ożywienia eksportu i ogólnej koniunktury także, wtedy gdy z punktu widzenia gospodarki jako całości było to niezbędne. Istotnym argumentem przeciwników wprowadzenia systemu izby walutowej w Argentynie była teza, że zmusi to kraj do akceptowania amerykańskiej polityki monetarnej również, w sytuacji gdy dla rodzimej gospodarki jest ona niekorzystna. Restrykcje monetarne w Stanach Zjednoczonych musiały wywołać odpowiedni wzrost stóp procentowych w Argentynie, co w razie wystąpienia w tym samym czasie tendencji spadkowych w argentyńskim PKB doprowadziłoby do pogłębienia się recesji. W rzeczywistości efekty „importu” polityki monetarnej były jeszcze bardziej niebezpiecz-

2 [Hausmann, 2001], powołując się na wyniki badań empirycznych, wskazał, że wymiana handlowa krajów, których waluty powiązane są sztywnym kursem, jest trzykrotnie wyższa, niż wynikałoby to $\mathrm{z}$ ich charakterystyk ekonomicznych. Oznacza to, że kryterium optymalnego obszaru walutowego dotyczące stopnia otwartości i intensywności wymiany nie jest egzogeniczne, lecz może być rezultatem przyjętego reżimu kursowego. W takim przypadku pogłębiająca się integracja rynków dóbr, czynników produkcji oraz rynku pieniężnego powoduje, że kryteria optymalnego obszaru walutowego mogą zostać spełnione niejako ex post. Ich brak nie jest więc - zdaniem autora - wystarczającym powodem dla rezygnacji z kursu sztywnego. 
ne: wzrost amerykańskich stóp procentowych o jeden punkt bazowy powodował ich podwyżkę w Argentynie w stosunku większym niż 1:13.

Rezultatem usztywnienia nominalnego kursu peso była jego znaczna realna aprecjacja. Realny efektywny (ważony handlem) kurs walutowy (REER) wzrósł między 1990 a 2000 rokiem o ponad 75\% [Perry, Servén, 2002]. Największy wzrost wartości waluty krajowej przypadł na okres do 1994 r., kiedy inflacja utrzymywała się jeszcze na dość znacznym poziomie; w początku lat 90. wielu ekonomistów było zdania, że ciągła aprecjacja REER jest usprawiedliwiona trwałym wzrostem produktywności gospodarki argentyńskiej w porównaniu z jej partnerami handlowymi. Przewaga ta miała być wynikiem korzystnych efektów reform gospodarczych przeprowadzonych w ramach Planu wymienialności.

Na poziom REER wpłynęło także wiele szoków zewnętrznych. Do najważniejszych można zaliczyć spadek terms of trade Argentyny w latach 1998-1999 (o ok. $11 \%$, [BCRA, 1999]), aprecjację dolara amerykańskiego w stosunku do głównych partnerów handlowych Argentyny - państw strefy euro, a przede wszystkim dewaluację brazylijskiego reala w styczniu 1999 r. W połączeniu ze stagnacją relatywnej produktywności spowodowało to, że już od 1998 r. REER był znacznie zawyżony. Szacuje się, że aprecjacja dolara względem euro oraz dewaluacja reala przyczyniły się do przewartościowania peso co najmniej w 70\% [BCRA, 1999].

Odchylenia realnego kursu wymiennego od poziomu równowagi mogą mieć miejsce zarówno w reżimie kursu stałego, jak i płynnego. Różnica polega na tym, że w warunkach kursu płynnego nierównowaga może być szybko wyeliminowana dzięki dostosowaniu nominalnego kursu wymiennego. W przypadku kursu sztywnego dostosowanie musi nastąpić poprzez zmiany w poziomie cen krajowych w stosunku do ich zagranicznych odpowiedników, co przy niskiej stopie inflacji u partnerów handlowych wymaga absolutnego spadku cen. Inercja wielkości nominalnych prowadzi do recesji ${ }^{4}$.

Dla zrozumienia przyczyn kryzysu warto także skupić się na relacji pomiędzy realnym kursem walutowym a zdolnością kraju do zaciągania kredytów za granicą, która w przypadku Argentyny spadła z wysokiego poziomu na początku lat 90 . do zera w $2001 \mathrm{r}$. W tym ujęciu perspektywy eksportowe determinują dostęp państwa do zagranicznych zasobów finansowych. Począwszy od 1999 r. oczekiwania dotyczące kształtowania się wartości eksportu spadły wraz ze spadkiem cen towarów eksportowych oraz realną aprecjacją peso. Będące rezultatem tego procesu drastyczne ograniczenie dostępu do źródeł finansowania częściowo wyjaśnia spadek inwestycji i recesję. Od tego momen-

3 [IMF Economic Forum, 1999]. W przypadku Argentyny stopy procentowe rosną o 2,7 punktu bazowego na każdy punkt bazowy w USA.

4 W rzeczywistości deflacja w Argentynie miała miejsce, lecz jej skala - 3\% w latach 1998.2000 - okazała się niewystarczająca dla zrównoważenia skutków szoków zewnętrznych [Perry, Servén, 2002]. Jednak szybsze tempo deflacji byłoby ze wzglẹdów politycznych trudne do osiągnięcia, gdyż wymagałoby jeszcze głębszej recesji i większego wzrostu bezrobocia. Zjawisko występowania recesji jako następstwa programu stabilizacyjnego opartego na kotwicy kursowej było znane i opracowane w literaturze, m.in. [Calvo, Végh, 1999], [Perry, 1997]. 
tu negatywne czynniki wzmacniały swoje działanie: wyższe premie za ryzyko i malejący napływ kapitału powodowały spadek produkcji, a ten z kolei w dalszym ciągu obniżał wiarygodność kraju i zmniejszał jego zdolność kredytową.

Ewolucja REER znalazła więc odzwierciedlenie w kształtowaniu się argentyńskiego eksportu. Przez większą część lat 90. jego realna wartość rosła, jednak w tempie słabszym, niż miało to miejsce w porównywalnych krajach. Analizy wykazały, że w 2001 r. peso było przewartościowane o ponad $40 \%$ [Hausmann, Velasco, 2000]. Przy rosnących kosztach pozyskania kapitału spowodowało to, że rozwój sektora eksportowego uległ zahamowaniu, co z kolei przyczyniało się do przedłużenia recesji, wzrostu bezrobocia oraz pogorszenia bilansu handlowego. Powstawała w ten sposób pośrednia zależność między reżimem kursowym a deficytem budżetowym; system kursu sztywnego przyczyniał się do zmniejszenia dochodów budżetu państwa, stwarzając - poprzez przewartościowanie waluty i spadek konkurencyjności eksportu, a tym samym obniżenie się dochodów przedsiębiorstw - bodźce do unikania płacenia podatków. Opóźnienia w dostosowaniu gospodarki do szoków zewnętrznych, wywołane utrzymywaniem sztywnego kursu w stosunku do dolara, oddziaływały więc na problem wypłacalności państwa za pośrednictwem dwóch kanałów: z jednej strony redukowały oczekiwane tempo wzrostu, z drugiej - utrudniały dostosowania fiskalne w miarę, jak spadała relacja dochodów podatkowych budżetu do PKB. W tym kontekście podwyżki podatków (np. w ramach programu Impuestazo w 2000 r.) lub cięcia wydatków publicznych (jak w drugiej połowie 2001 r.) przyczyniały się jedynie do pogłębienia recesji oraz wzrostu napięć społecznych i politycznych.

Druga zależność pomiędzy systemem walutowym a stanem budżetu państwa jest znacznie bardziej istotna. Sztywny kurs wymienny zachęcał podmioty krajowe - w tym również rząd - do zaciągania kredytów denominowanych w dolarach i innych walutach obcych. Na koniec 2001 r. tylko 3\% zadłużenia publicznego stanowiły kredyty zaciągnięte w peso [Porzecanski, 2002]. W sytuacji kiedy dług publiczny, przy stałym kursie wymiennym, sięgał 50\% PKB, nagła dewaluacja peso mogła spowodować jego natychmiastowy, znaczący wzrost, stanowiąc zagrożenie dla stabilności finansowej państwa. Przyjęte w Argentynie rozwiązanie, mające na celu zwiększenie elastyczności systemu izby walutowej poprzez dopuszczenie pokrycia do $1 / 3$ bazy monetarnej obligacjami rządowymi denominowanymi w USD, stanowiło dodatkowe źródło ryzyka. Obniżało ono wiarygodność systemu, w sytuacji kiedy ewentualne załamanie się finansów publicznych spowodowałoby natychmiastowy spadek wartości rezerw pokrywających bazę monetarną. W rezultacie do wzrostu premii za ryzyko krajowe Argentyny przyczyniały się więc obawy inwestorów dotyczące dwóch możliwości: po pierwsze, że władze Argentyny w trudnej sytuacji zdecydują się na zmianę reżimu kursowego, dążąc do poprawy konkurencyjności eksportu (ryzyko walutowe); po drugie, że rząd Argentyny okaże się niezdolny do spłaty zobowiązań, co - wobec bezpośredniego powiązania trwałości systemu kursowego ze stanem budżetu - mogłoby prowadzić do zmiany reżimu (ryzyko niewypłacalności). 
Odrębny problem, także oddziałujący na oczekiwania inwestorów, wiązał się z uprawnieniami banku centralnego, dającymi mu możliwość faktycznego podejmowania decyzji monetarnych o charakterze dyskrecjonalnym. Działania banku, mające na celu zapewnienie wsparcia dla sektora finansowego w sytuacji kryzysowej, pozostające w jego wyłącznej dyspozycji wobec braku ścisłych uregulowań prawnych, stwarzały zagrożenie, że restrykcyjne reguły systemu izby walutowej zostaną ominięte, a podaż pieniądza krajowego przekroczy limit wyznaczony ilością posiadanych rezerw zagranicznych. Rezultatem mogła być destabilizacja systemu finansowego, zwłaszcza jeśli wziąć pod uwagę, że peso nie zostało w pełni zaakceptowane jako środek przechowywania wartości ani przez podmioty zagraniczne, ani krajowe, co wynikało w dużej mierze z ogólnej historycznie niskiej wiarygodności władz monetarnych Argentyny oraz jej polityki gospodarczej.

Z obecnej perspektywy wydaje się jednak, że elementem decydującym o wystąpieniu kryzysu w Argentynie był ciągły i znaczny wzrost długu publicznego, którego konsekwencją okazała się niewypłacalność państwa. Władze Argentyny nie wykorzystały odpowiednio moźliwości dostosowań fiskalnych w latach prosperity poprzedzających 1999 r. Szacuje się, że gdyby zdołano w tym korzystnym ekonomicznie okresie - do 1999 r. - wypracować pierwotną nadwyżkę budżetową rzędu $2 \%$ PKB, zmniejszyłoby to sumę zadłużenia w $2001 \mathrm{r}$. o 60 mld dol. [Mussa, 2002], a tym samym wyeliminowało lub przynajmniej istotnie ograniczyło niepewność co do wypłacalności państwa w długim okresie, zapewniło niższe stopy procentowe i stworzyło lepsze środowisko dla przezwyciężania skutków kryzysów zewnętrznych. Jednocześnie realizacja takiej nadwyżki w czasie prosperity byłaby łatwiejsza zarówno ekonomicznie, jak i politycznie. Konieczne reformy w dziedzinie finansów publicznych odwlekano jednak zbyt długo i ostatecznie okazały się spóźnione.

Brak dyscypliny fiskalnej jako zasadnicza przyczyna kryzysu nie jest jednak akceptowany powszechnie i bez zastrzeżeń. Podkreśla się, że choć utrzymywanie dyscypliny fiskalnej niewątpliwie zmniejsza ryzyko kryzysu i ułatwia przezwyciężanie ewentualnej recesji, to jednak - co widać choćby na przykładzie kryzysu azjatyckiego - nie jest w stanie zupełnie wyeliminować zagrożenia [Hausmann, Velasco, 2001]. Ponadto według niektórych opinii ${ }^{5}$ sytuacja budżetu państwa w Argentynie nie była znacząco gorsza niż w innych krajach Ameryki Łacińskiej oraz pozostałych państwach z grupy emerging markets, przynajmniej do połowy $2001 \mathrm{r}$. Całkowity dług publiczny Argentyny zwiększył się z 33\% PKB w początku lat 90 . do $41 \%$ w 1998 r., a w 2000 r. przekroczył $50 \%$ [Perry, Servén, 2002]. Wciąż jednak - w porównaniu do kryterium $60 \%$ ustalonego w Maastricht dla członków Unii Europejskiej - wydawało się to poziomem bezpiecznym. Ale nawet ten stosunkowo niski współczynnik zadłużenia w przypadku Argentyny był niepokojący. W przeciwieństwie do krajów rozwiniętych, które w długim okresie zdolne są utrzymać nawet większy procentowo stosunek zadłużenia do PKB, system zbierania podatków w Argenty-

5 Np. [Perry, Servén, 2002], [Krueger, 2002]. 
nie był nieefektywny; całość dochodów podatkowych (łącznie ze składkami na ubezpieczenia społeczne) wynosiła niewiele ponad $20 \%$ PKB, podczas gdy w krajach rozwiniętych osiągała nawet 50\% PKB [Mussa, 2002]. Znaczący udział kredytów denominowanych w walutach obcych powodowal, że rząd Argentyny musiał przekonać wierzycieli nie tylko o tym, że będzie w stanie zebrać fundusze na spłatę zadłużenia, ale także, że zdoła dochody z podatków wymienić na waluty zagraniczne. Spadek dynamiki eksportu, traktowanej jako tradycyjny miernik zdolności państwa do spłaty kredytów zagranicznych, znacząco zachwiał wiarygodnością kredytową Argentyny.

Zbyt luźna polityka fiskalna powodowała też, że działania rządu musiały mieć procykliczny charakter także w sytuacjach trudnych dla gospodarki, przyczyniając się do pogłębienia recesji, wzrostu napięć społecznych lub wręcz kryzysów finansowych. W przypadku Argentyny dodatkowym problemem było powiązanie budżetu centralnego z finansami prowincji w taki sposób, że władze centralne zmuszone były pokrywać deficyty powstające lokalnie. Po uwzględnieniu tego zjawiska okazuje się, że skonsolidowany deficyt budżetowy osiagną̧ poziom 2,5\% PKB nawet w korzystnym dla gospodarki okresie 1997-1998 [Perry, Servén, 2002]. Byłby on jeszcze większy, gdyby nie przychody z tytułu prywatyzacji, przeznaczane częściowo na pokrycie bieżących wydatków. Całkowite wpływy rządu z podatków i prywatyzacji osiągnęły jednak maksymalną wartość w 1994 r. (24,3\% PKB) i od tego czasu ciągle spadały, mimo podwyżek stóp podatkowych, rozszerzania bazy podatkowej oraz manipulowania strukturą podatków [Porzecanski, 2002]. Recesja i pogarszanie się sytuacji przedsiębiorstw sprzyjały unikaniu płacenia podatków i rozwojowi „szarej strefy".

Do wzrostu deficytu przyczyniał się także przerost sektora publicznego. Zatrudniał on aż $12,5 \%$ siły roboczej - dla porównania, w Brazylii i Chile $7 \%$, $6 \%$ w Indonezji i Tajlandii, 8-10\% w Rosji, Turcji i RPA - przy czym średnie płace $\mathrm{w}$ tym sektorze przewyższały wynagrodzenia w firmach prywatnych o $25 \%$ w 1994 r., a w 1998 r. już o 45\% [Krueger, 2002]. Reforma systemu ubezpieczeń społecznych obciążyła budżet państwa równowartością 1\% PKB [BCRA, 1999]. Zjawisko to można było przewidzieć i podjąć odpowiednie środki zapobiegawcze, jednak tego nie uczyniono. Wydaje się, że zagrożenia związane z przerostem zadłużenia publicznego zostały zlekceważone.

Reformy budżetowe, przeprowadzone po 1998 r., okazały się niewystarczające. Ich nieadekwatność do rzeczywistych potrzeb jest jeszcze bardziej widoczna, jeśli uwzględnić bezpośredni i pośredni wpływ przewartościowania peso na bilans rządowy. W 2000 r. nadmierna aprecjacja kursu realnego spowodowała, że tradycyjnie obliczany stosunek długu publicznego do PKB był niedoszacowany o ok. $40 \%$, gdyż znaczna część zadłużenia denominowana była w dolarach, podczas gdy aktywa rządu (przede wszystkim dochody z podatków) opiewały na walutę krajową. Nawet gdyby system izby walutowej został utrzymany, konieczność korekty REER poprzez dewaluację ujawniłaby niezdolność rządu do spłaty zobowiązań. Utrzymanie wypłacalności wymagałoby zwiększenia nadwyżki budżetowej o ok. $2 \%$ rocznie - przy tempie wzrostu gospo- 
darczego rzędu 4\% [Pou, 2002] $]^{6}$. Reżim kursowy de facto ukrył przed społeczeństwem skalę trudności budżetowych i utrudnił uzyskanie szerokiego wsparcia dla dodatkowych reform fiskalnych.

W dwuwalutowym systemie monetarnym Argentyny znaczna część kontraktów finansowych denominowana była w dolarach. Wysoki procent portfela aktywów banków opiewał na dolary, a pod koniec 2001 r. w tej walucie wyrażone było ponad $80 \%$ długu publicznego [BCRA, 2001]. W tej sytuacji nawet przeciwnicy systemu izby walutowej, wskazujący na wysokie realne przewartościowanie peso, odnosili się sceptycznie do jego ewentualnej dewaluacji. Do powstania problemu związanego z niekorzystną strukturą walutową zobowiązań przyczyniła się w dużej mierze polityka rządu i banku centralnego, które traktowały zaciąganie kredytów dolarowych - bardziej kosztownych w przypadku dewaluacji peso - jako śrpdek zwiększenia wiarygodności systemu kursowego [Levy Yeyati, 2002]. W analogicznej jak rząd sytuacji znajdowały się liczne przedsiębiorstwa i gospodarstwa domowe - deflacja, podobnie jak dewaluacja, musiała w istotny sposób obniżyć ich zdolność do spłaty zadłużenia zarówno w dolarach, jak i w peso. Taka struktura walutowa zobowiązań, charakterystyczna dla krajów rozwijających się, wynika ze struktury międzynarodowego rynku kapitałowego. Kraje te nie są w stanie zaciągać kredytów zagranicznych we własnej walucie. Konsekwencje są bardzo istotne: niezależnie od reżimu kursowego realny kurs walutowy z reguły słabnie w czasie recesji, zwiększając ciężar zadłużenia i zmniejszając zdolność kredytową danego kraju dokładnie w tym czasie, kiedy najbardziej potrzebuje on dostępu do międzynarodowego kapitału. Utrata zdolności kredytowej działa jak kolejny negatywny szok, multiplikując skutki pierwszego i prowadząc często do załamania gospodarki.

W retrospektywnym ujęciu nasuwa się wniosek, że akumulacja zadłużenia zagranicznego w Argentynie powinna była osiągnąć mniejsze rozmiary. Nie jest natomiast jasne, w jaki sposób można było tego dokonać. Dużą część ogółu zadłużenia zewnętrznego stanowiły kredyty prywatne, pozostające poza kontrolą administracyjną. Jedyną opcją byłoby więc prowadzenie silnie antycyklicznej polityki fiskalnej, umożliwiającej osiągnięcie dużej nadwyżki budżetowej zawsze wtedy, kiedy rosły pożyczki zaciągane przez sektor prywatny, a tym samym utrzymanie równowagi w bilansie płatniczym. Alternatywa polegająca na jakiejś formie centralnej kontroli kredytów prywatnych - np. poprzez podatki - także mogłaby ograniczyć zaciąganie kredytów zagranicznych. Byłoby to jednak sprzeczne z jedną z podstawowych zasad strategii gospodar-

6 Autor podkreśla, że podstawowym założeniem przyjętym w obliczeniach byla restrukturyzacja zadłużenia zagranicznego, w szczególności odroczenie spłaty kapitału. Uzyskanie zgody wierzycieli zależało jednak od ich oczekiwań odnośnie tempa wzrostu gospodarczego i poziomu stóp procentowych, a także reakcji innych uczestników rynku. Gdyby gotowość wierzycieli do odroczenia splaty długu spadła, stopa wzrostu i nadwyżka budżetowa konieczna dla utrzymania wyplacalności wzrosłaby gwałtownic. Wzrost nadwyżki musiałby być równy rozmiarowi wydatków na obsługę zadłużenia, umożliwiających zachowanie dostępu do rynku kapitałowego. Dla przykładu, w 2000 r. koszty te szacowano na $15 \%$ PKB. 
czej Argentyny, polegającej na dążeniu do integracji z międzynarodowym rynkiem kapitałowym, nie zaś na ograniczaniu dostępu do niego.

Utrzymujący się przez większość dekady lat 90 . deficyt na rachunku obrotów bieżących stwarzał podwójne zagrożenie. Po pierwsze, zwiększał wrażliwość gospodarki na nagłe odwrócenie się kierunku przepływów kapitałowych; po drugie, przyczyniał się do realnego przewartościowania peso, gdyż część tego zjawiska wiąże się z pogorszeniem relacji aktywów zagranicznych netto do PKB. Relacja ta pozostaje w bezpośrednim związku z REER w punkcie równowagi; obniżenie wartości REER w punkcie równowagi oznacza większy stopień przewartościowania waluty przy danym kursie nominalnym.

Perspektywy rozwoju eksportu - w ocenie inwestorów - powodowały dalsze ograniczenie ich gotowości kredytowej względem Argentyny, gdyż były zbyt niskie w stosunku do jej zadłużenia zagranicznego. Jako kraj rozwijający się, obciążony znacznym zadłużeniem zagranicznym, Argentyna była wyjątkowo podatna na zmiany oczekiwań uczestników międzynarodowego rynku kapitałowego. Utrzymanie wypłacalności warunkowane było dostępem do kredytu, zaś dostęp do kredytu zależał od przekonania inwestorów o utrzymaniu się wypłacalności kraju w długim okresie. Historia niestabilności finansowej i politycznej nie sprzyjała pozyskaniu zaufania kredytodawców.

Jako jedną z przyczyn słabego rozwoju eksportu i związanego z tym ciągłego deficytu na rachunku obrotów bieżących wymienia się - paradoksalnie - członkostwo Argentyny w Mercosur [Edwards, 2002 a]. W opinii Banku Światowego Mercosur, ze swoimi wysokimi zewnętrznymi taryfami celnymi, stanowi typowy przykład strefy wolnego handlu, która de facto nie sprzyja zwiększaniu efektywności gospodarek państw członkowskich. Rzeczywista integracja z gospodarką światową wymagałaby całkowitego przeformułowania argentyńskiej polityki handlowej ${ }^{7}$.

Tradycyjnie "słabym punktem" argentyńskiej gospodarki był sektor bankowy. Szereg reform, przeprowadzonych w latach 90., przyczynił się jednak do radykalnej zmiany tej sytuacji. W 1998 r. argentyński sektor bankowy znalazł się na drugiej pozycji (jedynie za Singapurem, a przed Chile) w rankingu CAMELOT Banku Światowego [Perry, Servén, 2002]. Oceniany był on jako bardzo stabilny; krytyka reform dotyczyła niemal wyłącznie osłabienia jego efektywności w wyniku ustalenia zbyt wysokich wymogów płynnościowych i progów kapitałowych [Calomiris, Powell, 2000]. System bankowy był w dobrej kondycji nie tylko do momentu poprzedzającego dewaluację brazylijskiego reala, ale także później, do końca 2000 r., mimo utrzymującej się po styczniu 1999 r. recesji. Wskaźniki finansowe odzwierciedlały siłę systemu; rezerwy płynnościowe gwarantowały możliwość przetrzymania nawet znacznych szoków -

7 Jako przykład podaje się tu decyzję Chile o opuszczeniu Paktu Andyjskiego i dokonaniu jednostronnej liberalizacji warunków wymiany handlowej w latach 70 . Działania rządu argentyńskiego poszły jednak dokładnie w przeciwnym kierunku - zapowiedziano chronienie krajowego przemysłu poprzez nałożenie na podmioty publiczne obowiązku zakupu towarów argentyńskich (compra argentino), niezależnie od poziomu ich cen i jakości. 
łącznie z odpływem jednej trzeciej całości depozytów lub utratą 10\% portfela kredytów - nie stwarzając przy tym zagrożenia dla reżimu kursowego [de la Torre, et al., 2002]. Celem reform sektora bankowego było - pośrednio - dążenie do umocnienia wiarygodności systemu izby walutowej. Dwuwalutowy system przyczyniał się do używania dolara amerykańskiego w kontraktach finansowych. Utrzymująca się niepewność co do trwałości reżimu kursowego, znajdująca odbicie w premii za ryzyko, uniemożliwiała wladzom zastosowanie takich zmian regulacji sektora bankowego, które - wprowadzając zabezpieczenie systemu na wypadek dewaluacji peso - mogłyby sugerować inwestorom taką możliwość. Stąd nie pojawiły się żadne dążenia do ograniczenia udziału dolarowych depozytów lub kredytów w ich ilości ogółem. Udział depozytów dolarowych wzrósł po kryzysie rosyjskim oraz dewaluacji reala, szczególnie zaś od połowy 2001 r., kiedy groźba dewaluacji stawała się coraz bardziej rzeczywista. W tej sytuacji zmiana kursu wymiennego między peso a dolarem stanowiła istotne zagrożenie dla wypłacalności sektora bankowego.

Patrząc wstecz można wskazać na istnienie kilku podstawowych słabości argentyńskiego systemu bankowego, z których występowania i roli nie do końca zdawano sobie sprawę. Ograniczały one zdolność sektora bankowego do reagowania na pewne typy szoków, nawet w sytuacji gdyby system izby walutowej został utrzymany. Chodzi tu przede wszystkim o bezpośredni lub pośredni wpływ dostosowań deflacyjnych na wypłacalność kredytobiorców, w tym rządu. Stabilność sektora bankowego została uzależniona od stanu finansów publicznych poprzez posiadane przez banki obligacje rządowe. W Argentynie nie zdecydowano się na radykalny krok, jakim byłoby wyłączenie obligacji $\mathrm{z}$ instrumentów stanowiących zabezpieczenie płynności w ramach rezerw obowiązkowych; aż do 2000 r. obligacje długoterminowe traktowano jako obciążone zerowym ryzykiem, na równi $\mathrm{z}$ amerykańskimi. Od $2001 \mathrm{r}$. coraz trudniejszy dostęp do kredytów zagranicznych spowodował, że rósł rządowy nacisk na banki w celu skłonienia ich do zakupu obligacji.

Źródłem zagrożeń w sektorze bankowym było także zbytnie zaufanie do regulacji prawnych w zakresie rezerw obowiązkowych. Wysoki poziom rezerw bez wątpienia zwiększa odporność systemu bankowego na ataki spekulacyjne i nagły odpływ depozytów. W Argentynie zlekceważono jednak fakt, że w przypadku pojawienia się paniki wśród depozytariuszy redukcja poziomu rezerw w celu zwiększenia płynności mogła zostać odebrana jako osłabienie systemu izby walutowej, przyczyniając się do spadku zaufania uczestników rynku i wzrostu niepewności. Brak wiarygodnego pożyczkodawcy ostatniej szansy mógł spowodować załamanie się systemu nawet $\mathrm{w}$ momencie, kiedy ogólny poziom rezerw był jeszcze wysoki, ale konieczność wypłaty wszystkich wycofywanych depozytów oznaczała, że w pewnej chwili płynne zasoby okażą się niewystarczające [Chang, Velasco, 2000]. Dlatego też w systemie izby walutowej dobrym rozwiązaniem mogłoby się okazać objęcie wymogami rezerwowymi wszystkich depozytów na żądanie (co uchroniłoby depozytariuszy przed zamrożeniem wypłat) - i rezygnacja $\mathrm{z}$ objęcia nimi depozytów terminowych [Perry, Servén, 2002]. 
Rolę „zapalnika” kryzysu odegrały szoki polityczne. Dość paradoksalnie można stwierdzić, że kryzys w Argentynie nastąpił, ponieważ inwestorzy się go spodziewali [Velasco, 2002]. Dla gospodarki wykazującej słabości strukturalne działania o charakterze politycznym mają niebagatelne znaczenie. Jeśli prowadzą one do wątpliwości co do wypłacalności państwa, mogą spowodować wystąpienie "stadnych zachowań" inwestorów oraz samospełniających się oczekiwań, przenosząc gospodarkę z dobrego do złego punktu równowagi. W latach 1999-2001 wskazać można wiele wydarzeń politycznych, które w różnym stopniu przyczyniły się do zmiany punktu równowagi. Wzrost niepewności zaznaczył się po raz pierwszy w okresie przedwyborczym w 1999 r., kiedy prezydent Menem dążył do reelekcji, konkurując z kandydatem peronistów, Fernando de la Rúa. Po zwycięstwie nowej koalicji stało się jasne, że jej program różni się znacznie nie tylko w stosunku do poprzedników, ale także pomiędzy poszczególnymi frakcjami partii rządzącej. Spowodowało to wśród inwestorów wzrost niepewności co do nowej polityki gospodarczej, wyrażający się w postawie wyczekiwania i spadku aktywności. Obawy okazały się usprawiedliwione: politykom brakowało spójnego programu ekonomicznego, a sama koalicja okazała się nietrwała. Zmiana oczekiwań, wywołana przez szoki polityczne, początkowo łagodna, przyspieszyła w 2001 r., prowadząc do całkowitego odcięcia Argentyny od międzynarodowego rynku kapitałowego.

Za błędy w polityce gospodarczej Argentyny obarcza się często winą Międzynarodowy Fundusz Walutowy. Jeden z najistotniejszych zarzutów pod jego adresem dotyczy procyklicznego oddziaływania na przebieg kryzysu. Podkreśla się, że w czasie dobrej koniunktury Fundusz zachęcał do utrzymania systemu izby walutowej, natomiast w czasie kryzysu wycofał wsparcie finansowe [Blejer, et al., 2002]. Przedstawiciele Funduszu nie wykorzystali będących w ich gestii narzędzi nacisku na władze Argentyny w celu skłonienia ich do bardziej rozważnej polityki fiskalnej i zadłużeniowej. Kiedy w 1995 r. deficyt budżetowy Argentyny przekroczył uzgodnioną granicę, MFW zezwolił na odpowiednią korektę celu budżetowego. W warunkach recesji po kryzysie meksykańskim było to prawdopodobnie słuszne posunięcie. Jednak po roku 1995, kiedy gospodarka argentyńska odzyskała szybkie tempo wzrostu, wyższe niż przewidywane przez Fundusz, nie zareagował on odpowiednim obniżeniem dopuszczalnego deficytu. Nawet te wysokie progi były okresowo przekraczane, co jednak nie spotkało się z żadnymi sankcjami ze strony MFW. Problematyczną kwestią pozostaje jednak, czy wcześniejsze wprowadzenie restrykcji względem Argentyny mogło w jakikolwiek sposób umożliwić uniknięcie kryzysu lub choćby osłabienie jego konsekwencji. Nie wydaje się to prawdopodobne.

\section{Niewykorzystane srodki zaradcze}

W ujęciu retrospektywnym lata prosperity do połowy 1998 r. stanowią dla Argentyny straconą okazję. Jest pewne, że władze Argentyny nie podjęły wszystkich możliwych działań dla zminimalizowania ryzyka załamania gospodarcze- 
go, choć konkretne wskazanie tych działań jest już dla ekonomistów kwestią sporną. Przed wystąpieniem kryzysu panowała - nie tylko w samej Argentynie, ale także wśród jej zagranicznych doradców - powszechna zgoda, że reżim kursowy, stanowiący podstawę umowy społecznej, nie powinien ulec zmianie. Jednostkowe przeciwne opinie stanowiły raczej wyjątek od reguły.

Utrzymanie sztywnego kursu walutowego, a jednocześnie zminimalizowanie związanych z nim negatywnych efektów szoków zewnętrznych, wymagałoby w początkowym okresie [Perry, Servén, 2002]:

- radykalnego wzmocnienia dyscypliny budżetowej, nie tylko dla zwiększenia płynności, ale także w celu stworzenia miejsca na działania antycykliczne o charakterze fiskalnym;

- znaczącej poprawy elastyczności rynku pracy i innych rynków wewnętrznych;

- jednostronnego otwarcia na handel zagraniczny;

- dalszego wzmocnienia regulacji ostrożnościowych dla banków oraz zminimalizowania ich wrażliwości na sytuację budżetu państwa.

Żaden z tych postulatów nie został zrealizowany. Stało się tak w dużej mierze na skutek powszechnego braku świadomości, jak poważne okazać się mogą skutki zaniedbań. Warto zwrócić uwage, że problem nadmiernego wzrostu długu publicznego nie stał się przedmiotem szerszej debaty. Ani przedstawiciele MFW, uzgadniający z Argentyną warunki udzielenia pomocy finansowej, ani nawet opozycja polityczna wewnątrz kraju, nie wywarli odpowiedniego nacisku w tym kierunku. Należy jednak pamiętać, że nawet $w$ razie pojawienia się takich tendencji ich realizacja byłaby trudna ze względu na opór różnych grup społecznych, w których interesie leżało utrzymanie status quo.

Lata pomyślności mogły również zostać wykorzystane na opracowanie i realizację spójnej strategii zmiany systemu kursowego. To z kolei wymagałoby znaczących reform strukturalnych oraz instytucjonalnych, podczas gdy w omawianym okresie dominowało rozprężenie i zanik aktywności władz na wszystkich szczeblach.

Poniżej przedstawione zostaną propozycje reform, które na różnym etapie proponowane były przez same władze Argentyny bądź przez zagranicznych doradców, a z których z różnych powodów nie skorzystano.

\section{Wcześniejsze upłynnienie kursu peso}

Zmiana reżimu kursowego w stronę drugiego ekstremum - systemu kursu płynnego - mogła być rozwiązaniem korzystnym na pewnym etapie funkcjonowania Planu wymienialności. Uwolnienie kursu w odpowiednio wybranym momencie mogło przynieść wiele korzyści związanych ze zrównoważeniem bilansu płatniczego i redukcją tempa wzrostu zadłużenia zagranicznego, poprawą konkurencyjności eksportu, a tym samym zwiększeniem produkcji i zatrudnienia. Przeprowadzenie go przed dewaluacją brazylijskiego reala oraz spadkiem wartości euro $\mathrm{w}$ stosunku do dolara nie wiązałoby się z koniecznością tak znacznej nominalnej dewaluacji peso. Było to jednak trudne lub wręcz niemożliwe ze względu na ogromną wagę, jaką społeczeństwo przywiązywało 
do reżimu kursowego. Podstawową przyczyną były wciąż żywe obawy powrotu do niestabilności ekonomicznej i hiperinflacji. Zasadnicze niebezpieczeństwo polegało więc na tym, że zmiana systemu lub choćby próby złagodzenia go doprowadzić mogły do ponownego załamania się zaufania zarówno podmiotów krajowych, jak i inwestorów zagranicznych. Należy tu także uwzględnić wspomnianą już niekorzystną strukturę walutową zadłużenia publicznego i prywatnego, zwiększającą poczucie niepewności i nasilającą obawy inwestorów. Można wykazać, że w takich warunkach dewaluacja peso spowodowałaby spadek aktywności gospodarczej i pogłębienie recesji: wzrost kosztów obsługi zadłużenia powodowałby spadek popytu inwestycyjnego, przewyższający korzyści związane ze wzrostem eksportu, prowadząc tym samym do spadku popytu globalnego.

\section{Dolaryzacja}

Dla Argentyny - kraju, który przez wiele lat obywał się bez autonomicznej polityki pieniężnej - dolaryzacja mogła być dogodnym środkiem uzupełniającym przeprowadzone wcześniej reformy i umacniającym ich rezultaty. Wśród wielu ekonomistów popularne jest twierdzenie, że odpowiednio wczesna ${ }^{8}$ rezygnacja z systemu izby walutowej na rzecz pełnej dolaryzacji umoźliwiłaby uniknięcie załamania gospodarczego, zapobiegając panice na rynku finansowym. Dolaryzacja wiązałaby się prawdopodobnie z mniejszą skalą ucieczki depozytów już w trakcie trwania kryzysu. Wynika to z faktu, że duża część wycofywanych wkładów w peso powracała do systemu bankowego w postaci depozytów dolarowych, co oznacza, że inwestorzy bardziej niż zamrożenia wkładów obawiali się upłynnienia kursu, tym bardziej że w takim przypadku spodziewano się efektu "przestrzelenia" nominalnego kursu walutowego.

Należy jednak pamiętać, że choć dolaryzacja zmniejszyłaby prawdopodobieństwo paniki w sektorze bankowym, nie zdołałaby zapobiec negatywnemu wpływowi zjawisk deflacyjnych na wypłacalność podmiotów sektora dóbr niewymienialnych, a w rezultacie problemom sektora bankowego. Oznacza to, że także w przypadku zupełnej rezygnacji z waluty krajowej konieczna byłaby reforma rynków wewnętrznych, przede wszystkim rynku pracy.

Zasadniczą zaletą dolaryzacji byłoby utrzymanie w mocy umowy społecznej, gwarantującej wymienialność peso na dolary po kursie 1:1, umożliwiając zachowanie i wzmocnienie wiarygodności. Utrzymanie parytetu wiązałoby się ze znacznie mniejszymi kosztami politycznymi niż jego złamanie. Rząd Argentyny rozpatrywał opcję dolaryzacji w latach 1998-2000. Prowadzono w tym czasie nieformalne rozmowy z władzami USA, które aprobowały wprowadzenie dolara jako oficjalnej waluty w Argentynie, pod warunkiem, że nie żądałaby ona prawa głosu w kwestii prowadzenia amerykańskiej polityki monetarnej oraz zapewnienia pożyczkodawcy ostatniej instancji. Ewentualny podział

8 Tzn. przed 2001 r; niektórzy autorzy jako optymalną datę podają nawet rok 1996, kiedy system walutowy wykazał się zdolnością do przetrwania znacznych szoków zewnętrznych. Por. [de la Torre, et al., 2002], [Anthony, Hallet, 2000]. 
renty emisyjnej nie stanowił ważnej przeszkody w zawarciu porozumienia. Pomysł ten porzucono jednak w wyniku przesunięć na scenie politycznej ustępująca administracja Menema nie dysponowała wystarczającą dla zaakceptowania traktatu przewagą w Kongresie, natomiast nowy prezydent F. de la Rúa, głównie ze względów politycznych, był takiemu rozwiązaniu przeciwny.

Od 2001 r., kiedy zaufanie do władz ostatecznie spadło, dostęp do zagranicznych rynków finansowych został ograniczony i rozpoczął się proces ucieczki depozytów, prowadzący do spadku rezerw zagranicznych banku centralnego, dolaryzacja stała się znacznie trudniejsza do przeprowadzenia nie tylko politycznie, ale i ekonomicznie.

\section{Pesyfikacja uzupełniająca}

Dolaryzacja byłaby dla Argentyny rozwiązaniem bardziej korzystnym, gdyby towarzyszyło jej uelastycznienie wielkości nominalnych. Możliwość zwiększenia elastyczności zapewniłaby tzw. pesyfikacja uzupełniająca (pesification on the margin): wprowadzenie - spontaniczne lub planowe - nowej waluty krajowej dla celów transakcyjnych [Perry, Servén, 2002]. W Argentynie przed wybuchem kryzysu pojawiły się zaczątki tego procesu. Chodzi tu o quasi-pieniądz w formie obligacji rządu centralnego i władz prowincjonalnych. Działania te nie były planowane ani koordynowane. Emisja quasi-pieniądza w warunkach oficjalnej dolaryzacji stanowiłaby dodatkowe źródło finansowania wydatków publicznych, równoważące częściowo negatywny wpływ deflacji na strukturę aktywów i pasywów, umożliwiające poprawę sytuacji budżetowej oraz wyrównywanie relatywnych cen dóbr wymienialnych do niewymienialnych. Nowa „waluta” byłaby używana wyłącznie do celów zawierania transakcji, przy zachowaniu dolara jako środka przechowywania wartości. Byłaby także zewnętrznie niewymienialna, a jej kurs wewnętrzny płynny w stosunku do dolara. Moglaby uzyskać status prawnego środka płatniczego, przynajmniej dla celów podatkowych.

Pesyfikacja uzupełniająca pozwoliłaby na ograniczenie niespójności pomiędzy strukturą finansową i handlową a instytucjonalną - przypadkiem, kiedy powiązania handlowe i struktura produkcji przemawiają przeciwko wiązaniu własnej waluty z dolarem, natomiast historia niestabilności monetarnej i niepowodzenia kolejnych programów skłaniają do nieodwracalnej dolaryzacji.

\section{Unia walutowa}

Od 1999 r. prezydent F. de la Rúa proponował utworzenie unii monetarnej, łączącej członków Mercosur. Rozpoczęto negocjacje dotyczące umowy podobnej do traktatu z Maastricht, która określiłaby kryteria konieczne do spełnienia w drodze do unii gospodarczo-walutowej. Nawet w przypadku akceptacji tej koncepcji mogła ona jednak stanowić jedynie rozwiązanie długoterminowe - nigdzie poza Europą Zachodnią nie osiągnięto jeszcze takiego poziomu integracji gospodarczej i koordynacji polityki monetarnej, który umożliwiałby stworzenie unii. 


\section{System dual currency board}

Mimo licznych zalet sztywnego kursu walutowego dla wielu państw, zwłaszcza rozwijających się, powiązanie pieniądza krajowego $\mathrm{z}$ jedną tylko walutą nie jest rozwiązaniem optymalnym. Znaczne koszty pojawiają się, w przypadku kiedy gospodarka danego kraju doświadcza szoków nieskorelowanych z tymi, które dotykają państwo rezerwowe. Dywersyfikacja handlu może powodować dodatkowe straty, w sytuacji kiedy realna wartość danej waluty zmienia się w stosunku do walut innych - poza krajem rezerwowym - partnerów handlowych.

Negatywne zjawiska nie tylko wiążą się z pogorszeniem pozycji handlowej; mogą także naruszyć wiarygodność samego reżimu kursowego, jeśli skala wywołanych przez nie trudności gospodarczych odebrana będzie jako zagrożenie dla jego trwałości. Wzmocnieniu wiarygodności systemu izby walutowej może służyć powiązanie waluty krajowej z koszykiem walut zagranicznych [Oppers, 2000]. Powstaje wtedy automatyczny, kierowany przez rynek, mechanizm pozwalający na utrzymanie względnie stałej realnej wartości pieniądza krajowego, nawet w przypadku kiedy wzajemne kursy walut partnerów handlowych ulegają wahaniom. Podstawową korzyścią, jaką gospodarka czerpie z takiego systemu, jest możliwość „zmiany” kotwicy walutowej, w sytuacji kiedy dotychczasowa staje się z różnych powodów niekorzystna, bez naruszania wiarygodności systemu jako całości. Pozwala to na ograniczenie stopnia realnego przewartościowania pieniądza krajowego, a tym samym negatywnych skutków po stronie eksportu i bilansu handlowego. Jak długo emitenci użytych w systemie walut utrzymują politykę niskiej inflacji, tak długo wiązanie pieniądza krajowego $\mathrm{z}$ walutą ulegającą proporcjonalnie większej deprecjacji nie powinno prowadzić do pojawienia się znacznej inflacji krajowej.

Wprowadzenie „dualnego" systemu izby walutowej nie tylko było rozważane w Argentynie, ale również formalnie miało miejsce w czerwcu 2001 r. Kongres uchwalił zmianę ustawy o wymienialności i powiązanie peso $\mathrm{z}$ dolarem i euro od momentu, kiedy obie waluty osiągną parytet. Nie nastąpiło to jednak przed załamaniem się Planu wymienialności.

\section{Zaostrzenie polityki fiskalnej}

Nie został ostatecznie rozstrzygnięty problem, czy odpowiednio wcześnie przeprowadzone zmiany w polityce fiskalnej, mające na celu wypracowanie nadwyżki budżetowej, mogłyby pozwolić na uniknięcie kryzysu lub przynajmniej ograniczenie jego skutków. Według niektórych ekonomistów właściwym posunięciem byłoby ograniczenie wydatków rządowych, stwarzające miejsce na inwestycje prywatne. W najlepszym przypadku można by osiągnąć - zdaniem tych autorów - ekspansywny efekt zaostrzonej polityki fiskalnej: wzrost wydatków prywatnych przewyższający redukcję wydatków publicznych i powodujący tym samym zwiększenie się produkcji i popytu [Hausmann, Velasco, 2000]. Ekonomiczne uzasadnienie takiego założenia jest jednak wątpliwe. Całkowity popyt krajowy nie wzrasta na skutek ograniczenia wydatków rządowych między innymi dlatego, że udział importu w inwestycjach i konsumpcji jest 
zwykle większy niż w wydatkach publicznych. W efekcie więc popyt krajowy spada, a w ślad za nim także $\mathrm{PKB}^{9}$. Ostateczny efekt tych działań zależy niemal wyłącznie od wpływu, jaki wywierają one na przekonania inwestorów co do przyszłej wypłacalności państwa. Odebranie przez nich redukcji wydatków fiskalnych jako dowodu niemożliwych do opanowania trudności budżetowych przenosi gospodarkę do „złego” punktu równowagi. W przypadku Argentyny sposób rozumienia przez inwestorów nagłych cięć fiskalnych jest jednoznaczny: tego samego dnia, kiedy D. Cavallo ogłosił program zerowego deficytu (15 lipca 2001 r.), premia za ryzyko krajowe wzrosła z 1200 do 1600 punktów bazowych [Hausmann, Velasco, 2000].

\section{Uwagi koncowe}

O okresie 1996-1998 [Edwards, 2002b] powiedział, że Argentyna „zasnęła nad kierownicą". Do największych problemów, jakie ujawniły się w tym okresie, a którym nie towarzyszyły odpowiednie działania zapobiegawcze, zaliczył on rosnący dług publiczny, niezdolność państwa do renegocjacji umów finansowych zawartych z prowincjami, przewartościowanie peso i spadek międzynarodowej konkurencyjności argentyńskiego eksportu, utrzymujące się bezrobocie, wynikające z niedostatecznego zreformowania rynku pracy, obniżenie efektywności i koszty wiążące się z państwem opiekuńczym, rosnący deficyt handlowy oraz czynniki zewnętrzne.

Biorąc pod uwagę skalę szoków zewnętrznych, uderzających w gospodarkę Argentyny w latach 1998-2000 oraz odziedziczony z przeszłości poziom zadłużenia zagranicznego, rzeczywiste możliwości działania rządu były bardzo ograniczone. Jednak wielu autorów zgodnych jest w opinii, że podjęte przez władze argentyńskie w sytuacji kryzysowej decyzje nie były właściwymi. Rezygnacja z wymienialności poprzez pesyfikację, czyli przymusową konwersję wszystkich kontraktów krajowych z dolarów na peso, a następnie upłynnienie kursu walutowego, była najmniej pożądaną - pod względem skutków tak politycznych, jak i gospodarczych oraz społecznych - strategią zmiany reżimu kursowego. Zdaniem niektórych właśnie takie działanie sprawiło, że poważny kryzys przerodził się w ogólnogospodarczą katastrofę bez precedensu.

Jako moment graniczny - ten, w którym uniknięcie katastrofy było jeszcze możliwe - podaje się rok 1999 [Pou, 2002]. [Mussa, 2002] twierdzi nawet, że także w 2000 r. nie było za późno, gdyby w porę zdołano przeprowadzić do-

9 Wnioski te dotyczą analiży dla jednego okresu i pomijają wpływ zwiększonych inwestycji bieżących na poziom produkcji w okresach kolejnych. Zwolennicy tezy o ekspansywnym efekcie cięć w wydatkach publicznych argumentują, że większa produkcja, a tym samym większe zdolności eksportowe, przyczyniają się - poprzez zwiększenie zaufania inwestorów do wypłacalności państwa w długim okresie - do dalszego wzrostu inwestycji i produkcji. Nie uwzględniają oni jednak faktu, że zwiększony eksport możliwy jest tylko w przypadku rosnącego zagranicznego popytu na produkty krajowe, jest wiẹc czynnikiem egzogenicznym [Hausmann, Velasco, 2000]. 
stosowania fiskalne niezbędne dla przekonania inwestorów o możliwości utrzymania długookresowej wypłacalności państwa. Potwierdzeniem tego punktu widzenia był wciąż znaczny poziom rezerw zagranicznych banku centralnego, przekraczający ze sporym zapasem wielkość bazy monetarnej. Rekordowo wysoka była także suma depozytów w sektorze bankowym. W tym okresie pogorszenie się pozycji Argentyny na międzynarodowym rynku kapitałowym nie wpłynęło znacząco na sytuację w krajowym systemie finansowym. Według [Cavallo, 2002] program uzgodniony z MFW na 2001 r. dawał szanse już nie na uniknięcie kryzysu, ale na ograniczenie jego skutków i zapobieżenie jego przeobrażeniu się w gospodarczą i społeczną katastrofę. Ostatecznym końcem nadziei było przekroczenie celów fiskalnych programu w marcu $2001 \mathrm{r}$.

Kształtowanie się wskaźników ekonomicznych pozwala obecnie na stwierdzenie, że najgłębsza faza kryzysu w Argentynie została przezwyciężona: PKB wzrasta, kurs peso względem dolara ustabilizował się, zwiększa się suma depozytów w krajowym sektorze bankowym. Sytuacja jest jednak niezwykle trudna, przede wszystkim z uwagi na najpoważniejszy od dziesięcioleci kryzys zaufania społecznego do rządu i jego polityki. Tymczasem powodzenie gospodarczej odbudowy zależy przede wszystkim od uzyskania zaufania, nie tylko podmiotów krajowych, ale także - lub nawet przede wszystkim - partnerów zagranicznych, których wsparcie jest absolutnie niezbędne.

\section{Bibliografia}

Anthony M.L., Hallet A.H., [2000], Should Argentina adopt the US dollar?, CEPR Discussion Paper No. 2412.

Antinolfi G., Keister T., [2001], Dollarization as a Monetary Arrangement for Emerging Market Economies, Federal Reserve Bank of St. Louis Review, Nov./Dec. 2001.

BCRA, [1999], Report to the National Congress.

BCRA, [2001], Report to the National Congress.

Blejer M.I., Henke A., Levy Yeyati E., [2002], The Argentine Crisis: Issues for Discussion, www.nber.org/crisis/argentinaprg.html z dn. 21.12.2002.

Calomiris Ch.W., Powell A., [2000], Can emerging market bank regulators establish credible discipline? The Case of Argentina, 1992-99, NBER Working Paper No. 7715.

Calvo G.A., Végh C.A., [1999], Inflation Stabilization and BOP Crises in Developing Countries, NBER Working Paper No. 6925.

Cavallo D.F., [2002], The Fight to Avoid Default and Preserve Convertibility, www.nber.org/crisis/argentinaprg.html z dn. 21.12.2002.

Chang R., Velasco A., [2000], Exchange-Rate Policy for Developing Countries, AEA Papers and Proceedings, Vol. 90 No. 2, May 2000.

de la Torre A., Levy Yeyati E., Schmukler S.E., [2002], Argentina's Financial Crisis: Floating Money, Shrinking Banking.

Edwards S., [2002a], A simple Answer for Argentina: Follow Chile's Example, The Wall Street Journal, January $25^{\text {th }}$.

Edwards S., [2002b], The Argentine Debt Crisis of 2001-2002: A Chronology and some Key Policy Issues.

Hausmann R., Plan B: A way out of Argentina, 2001. 
Hausmann R., Velasco A., [2000], Hard Money's Soft Underbelly: Understanding the Argentyna Crisis, Kennedy School of Government, Harvard University.

IMF Economic Forum: Dollarisation: Fad or Future for Latin America?, June 24th, 1999, www.imf.org z dn. 16.02.02.

Iwanicz-Drozdowska M. (red.), [2002], Kryzysy bankowe. Przyczyny i rozwiazania, PWE, Warszawa.

Krueger A., [2002], Crisis Prevention and Resolution: Lessons from Argentina, www.imf.org z dn. 28.08.2002.

Levy Yeyati E., [2002], Presentation at the Bankg Panel, www.nber.org/crisis/argentinaprg.html z dn. 29.07.2002.

Małecki W., Sławiński A., Piasecki R., Zuławska U., [2001], Kryzysy walutowe, Wyd. Naukowe PWN, Warszawa.

Mussa M., [2002], Argentina and the Fund: From Triumph to Tragedy, Institute for International Economics, Washington DC.

Oppers S.E., [2000], Dual Currency Boards: A Proposal for Currency Stability, IMF Working Paper No. 199.

Perry G., [1997], Currency Boards and external shocks: How much pain, how much gain?, World Bank Latin and Caribbean Studies, Washington.

Perry G., Servén L., [2002], The Anatomy of Multiple Crises: Why was Argentina special and what can we learn from it, The Wordl Bank.

Porzecanski A., [2002], Argentina: The root cause of the disaster, www.nber.org/crisis/argentinaprg.html z dn. 29.07.2002.

Pou P., [2002], The Argentine Crisis, www.nber.org/crisis/argentinaprg.html z dn. 29.07.2002.

Veganzonés M.A., Winograd Ch., [1997], Argentina in the 20 $0^{\text {th }}$ Century: An Account of Long Awaited Growth, OECD Development Center Studies.

Velasco A., [2002], Argentina's Bankruptcy Foretold, Time, Latin American Edition, July 23rd. von Stein J.H. (Hrsg.), [2001], Die Finanzsysteme in Argentinien, Brasilien und Chile, Fritz Knapp Verlag, Frankfurt am Mein.

Żuławska U., [1994], Stabilizowanie gospodarki a wzrost. Doświadczenia Argentyny, Brazylii, Chile $i$ Meksyku, Studia i Materiały CESLA, Warszawa.

\section{THE ARGENTINE CRISIS OF 1999-2002 AND UNUSED REMEDIES}

\section{Summary}

This article presents an analysis of factors responsible for the Argentine crisis of 1999-2002. The first section of the study presents alternative approaches to underlying causes of the crisis, including mostly monetary and fiscal policy errors, wrong structure of the banking sector, as well as political or external shocks. The latter include, first of all, consequences of the Brazilian crisis, the dollar appreciation against the euro and unfavourable terms of trade. Emphasis has been put on controversy accompanying the specification of factors which finally resulted in the outbreak of the crisis and determined its scale.

The second section deals with a description of measures which might have averted the crisis, but had not been implemented for various reasons. The failure to apply remedies at the right time resulted in the crisis turning into an economic and social disaster. 